\title{
Implementation of the Ethical Knowledge in the Higher Economic Education
}

\author{
By Daphne Vidanec *
}

\begin{abstract}
As relatively new philosophical discipline, business ethics has sprang out from the business practice in the last quarter of the 20th century. Business ethics is focused on evaluation of business conduction of both individuals and corporations in the business world. Nowadays, in the public and academic milieu of the modern Western societies business ethics is recognized as one of the crucial educational forms, especially in the field of higher economically profiled institutions: faculties of economy, accredited colleges for business and management and the like. Analyzing socio-cultural, political and economic milieu of some European societies that went through certain social, juridical, political and economic metamorphoses since the fall of the Berlin Wall, what we can notice is certain fall of crucial human and social values: social and economic justice, economic equality, social freedom etc. The main task of the business ethics in the field of education is to show how we can build both, individual and social life as rational, socially engaged beings gifted by the capacity of understanding and of reasoning ourselves, our deeds, desires, decisions, choices. In this written elaboration the author tends to investigate and to describe the structure of the ethical education in the contemporary economic higher education through the prism of development and rise of modern economic theory.
\end{abstract}

\section{Introduction}

Under this title I want to introduce potential readers into the key problems which are of my concern here: 1) the future of higher education in the field of economics and 2) the role of ethics in it. This elaboration is a result of broader inquiry made on the basis of my earlier oral elaboration I have been presenting in occasion of the $16^{\text {th }}$ Annual Conference on Education in Athens - Greece from $19^{\text {th }}$ to $22^{\text {nd }}$ of May 2014. Considering the given time during the Conference speech, my opportunity to clarify some problems I have been discussing there in brief came in the form of extent elaboration I intent to expose in the following pages. And I shall do my best efforts explaining the issue of the subject I am dealing with here: the problem of economics in the higher education - as I see it through the prism of historical development of

"Senior Lecturer (in progress), Balthazar Zaprešić University of Applied Sciences, Croatia. 
economic theory which was conceived in Aristotelian era, but fully structured in the modern age, ending up with Keynesianism in $20^{\text {th }}$ c. A. D. My motivation for being involved with economics came out of my personal engagement with Business Ethics. The great part of teaching and studying ethical problems attached to the business world is related with recent global economic crisis occurred in 2008, and its moral, economic, social and political consequences that have affected mainly (small) economies in transition such as Croatian one.

\section{On Selected Subjects of Business Ethics Inquiry}

\section{Philosophical View of Questions Concerning (Higher) Economic Education}

The questions concerning the current status of higher economic education are related with the two: 1) the importance of Keynesian view (of economic problems) within contemporary economic education and business practice, too and the role of ethics ${ }^{1}$ in it.

One among the most influential economic theorists of $20^{\text {th }}$ century, John Maynard Keynes (1883 - 1946) has almost hundred years ago noticed that solution of the economic crisis lies in the nature of understanding of the main economic postulates and theories coined in late $18^{\text {th }}$ and during the $19^{\text {th }}$ century. Keynes's approach to explaining of existing ${ }^{2}$ economic theory (whose consequences are pretty recognizable in business practice related to the trade market which was hit by deep financial crisis in 1929) expressed and discussed at length in his major work published in 1936 under the title General Theory of Employment, Interest and Money we might take as theoretical basis in shaping philosophical origins of economic science. Insight into the genesis of modern economic science offered by Keynes we will define as 'economic intellectualism,', which is - in our opinion - inspired by certain ancient Greek outlooks (e. g. of Socrates and of Aristotle).

Speaking of the current status of (global) economy we might say that the first decade of $3^{\text {rd }}$ millennium was a period of new economic clash challenged by - what Keynes almost hundred years ago described in his famous phrase "dark forces of time and imperfect knowledge" (Keynes quoted by: Weitzman, 1993). That was a time when some world leading politicians (e. g. G. W. Busch, B. Obama) decided to make a shift in American economic policy by reviving Keynesian economic principles into flawed economic policy (consequentially implemented in practice due to widely accepted theory coined by 'classics') in order to find new economic solutions suitable in overcoming recent global financial crisis. Referring to what is discussed in previous lines, reasonable questions might come to one's mind: Why Keynes and how his economic theory can be helpful in solving recent economic crisis? - The

\footnotetext{
${ }^{1}$ The term Ethics is related to ethical theories and axioms applied into business practice and higher economic education.

${ }^{2}$ The term refers to the classical economic theory mainly formulated by A. Smith.

${ }^{3}$ Phrase coined by the author of this elaboration.
} 
Keynesian view of economic problems is rooted in deep philosophical insight into the genesis of anomalies of modern science of economy conceived in $18^{\text {th }}$ and $19^{\text {th }}$ century. From the socio-cultural point of view, we speak of time of great industrial revolution occurred in the modern West which was led by onwards intellectuals (mainly sprang out from Anglo Saxon - British speaking area) who were engaged with idea of building economically stable society of production, consumption and of free market trading. For them the affirmation of "good live" was the goal which could be achieved through permanent empowering of the economic stability and progress of community members. And community progress was strictly seen as economically engaged agency maintained by business elites towards happiness increasing through constant accumulation of goods - of capital. ${ }^{1}$ Such idea was originated in scientific thought of great thinkers, economists and scientists of the $18^{\text {th }}$ and $19^{\text {th }}$ century: Adam Smith, Ricardo, Bentham, Mill, Malthus, Marshall, Marx, Darwin, Spencer and Huxley and was taken as theoretical base of new economic and social world order: capitalism. My thesis ${ }^{2}$ is that contemporary education in the field of economics is reduced to the ruthless and nefarious training of young people: of future economists and of those who want to be engaged with making business of how to become successful business predators instead of being highly educated economic specialists engaged with strong moral sense. This theoretical position is not the new one. Its origins draw backwards into the era of great scientific names gathered around Darwinian evolutionary theory (Darwin, 1859) ${ }^{3}$. Business Ethics (further quoted: $B E$ ) appeared as certain antithesis to this naturalistic - better say - secular approach to learning economics. $B E$ is new philosophical discipline emerged from the need for 'revising' modern and deviated business practice and it is oriented towards building of moral reasoning of individuals and groups of people engaged with multifaceted business sphere - of course within different, multicultural milieus.

As new educational branch appeared in the field of higher economic education in the last two or three decades, $B E$ is taken not as serious as it should be according to its originally meaning coined by ancient Greeks: ethos in English: "habit, custom, human temperament or character". Aristotelian definition of ethics presupposes 'knowledge of good' that is seen as final telos achieved by long-term and lifelong learning. In the age we live ethics became let me borrow Ernst Tugendhat's term - a certain "label" applied to many institutions and companies involved with (making) business. It is wrong path! The role of $B E$ is associated with framing the moral horizons related to human agency in business world and in life, in general. We are speaking here of ethics as of télos itself.

\footnotetext{
${ }^{1}$ This principle is widely recognizable as Mill's "happiness maximization principle" grounded in modern utilitarian outlook.

${ }^{2} \mathrm{My}$ thesis is grounded in deep insight into professional economics literature concerning economic theories and practice, as well; as into relevant philosophical sources associated with Aristotelian outlook referred to Charles Taylor's historical-philosophical critique of the moral sources of human agency.

${ }^{3}$ Darwin cited according to Michael Ruse in: Th. H. Huxley, Evolution and Ethics, Princeton University Press, Princeton and Oxford, 2009, pp. vii.
} 
In the following explication I shall try to describe connection between $B E$, Keynesianism and the Economics in the field of higher education with an emphasis on ethical naturalism (that is, secularism) related to the contemporary business practice.

\title{
Metamorphoses of Economics
}

\section{The Ancient Polis-Economy Viewed Through the Value of Moral Reasoning}

Under the term of economy we might understood entire intellectually and physically boosted process of mankind with the purpose of achieving the "good life" - in the Aristotelian sense. The term economy is tight connected with the life concept. Following etymologically explanation of the term economy derived from the ancient Greek words olкo - Engl. "house; home; household" and vó $\mu o \varsigma$ - Engl. "law", we can define it as "an art of managing the household" (Aristotle: Nicomachean Ethics I). This definition involves having the sense of production and equal distribution of life goods that are necessary for building one's good life (taken as micro-economic sphere) within polis considered as macro-economic one. According to Aristotle $\left(4^{\text {th }}\right.$ c. B. C. $)$ making the good life project is not considered only as final purpose that humans are attracted to it by their nature but, the rational activity which divides humans from other living species within some existential environment. Making the life project - in the context of economy issue - is, for Aristotle, natural tendency of humans. Building the polis-economy for Aristotle meant actively participating of all polis members in long-term process that should be based in virtue concept. Many centuries afterwards, this virtue concept related to economics is re-defined by John Maynard Keynes. In his article entitled Economic Possibilities for Our Grandchildren issued in 1930 Keynes wrote:

\begin{abstract}
"(w)hen the accumulation of wealth is no longer of high social importance, there will be great changes in the code of morals. We shall be able to rid ourselves of the many of pseudo-moral principles which hag-ridden us for two hundred years, by which we have exalted some of the most distasteful of human qualities into the position of the highest virtues." (Keynes, 1930)
\end{abstract}

Being virtuous - in ancient time - was not an issue of any kind of moral state or position; it was not a kind of sense, rather it was taken as permanent activity towards shaping one's moral life - within micro-sphere, but simultaneously attached to the macro-sphere. ${ }^{1}$ And the great part in the process

\footnotetext{
${ }^{1}$ The term micro-sphere I use here in the sense of one's personal place or role within certain small economic community. Small economic community can be seen as certain family (in Aristotelian meaning), weather private one - whose members are tight connected among themselves with blood line; or public one: a company or a firm, whose members are deeply connected with a sense of the same or - at least of similar goals which presuppose different forms of public or business cooperation within some business community. The other term related to the macro-sphere concept I use in a sense of broader community, such as polis, or
} 
of achieving moral life belongs to the role of moral reason(ing): contemplation or theoria - embedded in human practice. This idea can be seen as certain dialectic of human agency. The conflicting goals principle of the human agency can be solved by selecting neither of given goals, which are in mutual conflict, yet humans are called upon to upgrade their intellectual efforts in achieving "the golden mean" on their particular way to the final end which is universal: thanatos. To overcome the idea of thanatos Greek thinkers have been invented certain mind skills which can help one to transcends his or her reality (which was usually destructed by warfare and whereas the peace was considered as intermezzo between repeatedly war-times). For them happiness is considered as the highlights of mind activity. The real happiness consists in making oneself immortal, and the only way to reach immortality - as Aristotle discusses in his writings - is contemplation. Being immortal in Aristotle philosophical manner meant to participate - continuously - in the process of thinking. Just thinking of the idea of immortality makes one man already immortal. So, Aristotelian conception of happiness related to the poliseconomy issue I will define as economy of the happiness, because it is grounded in human intellectual and physical efforts known under the term of (mental) labor, and happiness is labor itself: constant activity which presents certain joint venture contract between spiritual (mental) and material (physical) sphere. Projecting happiness - in Aristotelian philosophical manner, we might consider as theoretical framework for projecting moral life - or, in our case moral economy. For Aristotle, I might say, economy itself is an art of making a plan of life and this plan has to be grounded in virtue, because the virtue is the highest ethical value and, no other creature in the nature - except man itself is capable to establish a form of life which presupposes morally engaged activities. It is not a question of life organization (recognizable within community of bees or ants, too), rather of having a sense of what life really should be beyond this material sphere. It is a question of one's giving certain meaningful form to his or her life (Aristotelian notion of causa formalis), and happiness is a form of that kind. It includes both micro and macro life sphere.

Aristotelian picture of economy is colored by pure morality which is achievable through (what we might call) 'joint venture contract': a contract between morally engaged activities which spring from the same source and, weather they are related to mind or character, they always come in unique form: virtue itself.

Referring to polis-economy issue, we speak of virtue of prudence and of justice as of two the most important virtues attached to the human agency applicable to economic practice. Among countless philosophical outlooks we can find within history of philosophy since ancient time to onwards, when speaking of contemporary economy and business world, the most applicable one is that of Aristotle, because it discusses in inclusive way about fundaments that our life consists in: (moral) reasoning, social justice, civil life organization, politics, education, religion and many other things which are of great

state or any other form of joint venture contract related to achieving economic goals at broader - global level. 
importance in understanding of the meaning of human existence within given time and space.

\section{Convergences and Divergences concerning Micro and Macro Moral Sphere}

There are great similarities between Aristotelian and Keynesian view of the role of thinking. In my opinion, Keynes's theoretical position explicated in General Theory is, actually, Aristotelian - in the segment related to the morally based reasoning issue. Keynes said that has nothing been changed since the beginning of the history of mankind, not even the ratio of our fulfillment: we are all "old Adam" - in a way:

"(f)or many ages to come the old Adam will be strong in us that everybody will need to do some work if he is to be contented." (Keynes, 1930).

Yet, Keynes was right when saying that we are dealing with "widely mistaken interpretation of what is happening to us" now and that "we are suffering from the problem of misunderstanding the notion of the quick changes occurred in $19^{\text {th }}$ century (Keynes, 1930). What Keynes had noticed, when analyzing causes of economic crisis occurred in late 1920s, is that whole economic picture of modern age is, actually, expression of the fallacious economic theory, not of practice. But, practice speaks for itself and it speaks of "uncertain" future due to unstable and fragile presence designated by powerful (economic) crisis and the lack of "perfect knowledge", as well. Uncertain economic future issue discussed by Keynes within time zone related to mid thirties of $20^{\text {th }}$ century is a question or thesis formulated in a manner rather specific to philosopher then to somebody who is involved with economic profession - as Keynes surely was. He is searching for answers to the question concerning survival of the mankind in the future: what would our life look like in hundred years? And he serves us pretty prophetic answer by explaining that all kind of economic problems will be vanished in hundred years. For that time and in the eyes of Keynes's fellow economists such thesis was considered as very lucid and unacceptable one, because widely accepted economic outlook was the one which was originated by Adam Smith in his The Wealth of Nations: "self-regulatory economic policy" principle. In order to clarify his prophetic claim launched in the essay on economic possibilities of the mankind in the future (Keynes, 1930), Keynes is undertaking certain theoretical venture by writing a book dedicated to his colleagues: General Theory. This book became Holy Scripture of $20^{\text {th }}$ century economic science because its main idea is related to the role of labor within capitalistic economy. And the role of labor is explicated through analysis of the following issues: employment, money and rate of interests related to the questions of monetary policy. In order to prevent present (economic) expectations we have to face with past expectations, because it is the past which can give us right direction towards solving

\footnotetext{
${ }^{1}$ Keynes's term for knowledge implicit to economic profession, but goes beyond scientifically based explanations: certain philosophical view to economic theory.
} 
problems in the future. In other words, what Keynes wants to say is that our existence is limited by time machine and what had occurred in the past may affect our lives in the future. And Keynes was right: after the struggling against the crisis in 1929 had finished, population of the third millennium is faced with the new one: much stronger and deeper than the one of Keynesian era. And we may ask: Why? - The answer on the given question is very simply: because of disproportionality between long term business expectation and short term investments. After the year of 1929 who can assure us in accuracy, durability and cost effectiveness of economic calculations made by highly trained economic specialist who swear by the credibility and viability of all future investments, as Keynes put it: "when in the long run we are all dead"?!

In Keynes's view, the causes of economic crisis (in 1929) lie in the theory, not in the practice itself, because the practice is nothing but applied economic theory. The problem of misinterpreted economic theory Keynes defined as "dark forces of time and imperfect knowledge" phenomenon. This phrase "imperfect knowledge" involves certain ignorance as a result of the lack of moral knowledge in both theory and practice. For Keynes, moral knowledge, as I see it, is a synonym for what I shall call here 'thinking as philosopher, but acting as practitioner - when is about economic crisis.

What I have described in previous pages is subject related to the question I am dealing with here: theoretical base of understanding foundations of the economic science regarding its meaning in the ancient time designated by Aristotelian thought $\left(4^{\text {th }}\right.$ c. B. C. $)$, whereas economics is not considered in terms of modern economic science built on varieties of axioms and postulates (mainly expressed in mathematical language), but taken as applied knowledge of 'how to' organize (material aspect of) life within certain state formation known under the term of polis. It is "know how" principle that ancient economy was built on. But, this "know how" principle related to (what I might call) 'economic system' defended by Aristotle ${ }^{1}$ can be described in term of communitarian economy (in our time comparable with high economic standards specific for Scandinavian society), because the term "how" presupposes a certain (economic) method whose final ends are desirable not only for polis-community elites but for entire polis-community. On the other hand, economic arrangements made by polis-members are put under control of the polis-government due to its constitutional provisions. My claim is that the ancient Greek economic system is formed by strong juridical character expressed in the form of different rules and norms applicable to certain poliscommunity. It is conventionality that shapes ancient Greek concept of economy. Another term for what we might understand under the term of conventionality is ethics. Ethics is horizon within which economic

\footnotetext{
${ }^{1}$ Aristotle's conception of economy assumes different economic activities and organization of the city-state discussed at length in VII. and VIII. chapter in his Politics; for an instance: the right to private ownership and to benefit the general welfare, exchange and merchandise trade only can be done among different city-states within the Greek peninsula, but external trading is excluded because Aristotle was thinking that oversees economic activities could be a great threat to one polis stability.
} 
arrangements should circulate. For Socrates (according to Plato's Crito) ethics involves 'obeying' the polis laws; for Plato himself ethics was taken as horizon of eternal "Goodness". Unlikely the two thinkers previously mentioned, for Aristotle himself ethics is considered as unavoidable practical knowledge required in building once happiness and what takes lifelong both personal and public engagements that all society members must be ready to undertake by making their particular contribution in it. And speaking of the role of economics in it, tracing Aristotle we might conclude that economics refers to entire process of designing a "good", that is, a "happy life" - of course, in a sense of "know how" distributing of varieties of the goods that are of great necessity in affirming and preserving biological aspect of human life: in order to act as morally and politically fully engaged human being, one must first satisfy his or her biological needs and what depends on both quality and quantity of economic goods that certain (political or economic ${ }^{1}$ ) community disposes among its members. Considering Aristotelian conception of poliseconomy, I might say that is very difficult to determine at which point the ethics and economics are of touch and in which they differ - of course, when speaking of "good life".

Aristotelian concept of economy represented in his ethical and political writings is neither socialistic, nor capitalistic rather it is more closer to the Judeo-Christian outlook: be good, be diligent, be prudent and socially fully engaged, but above all do not forget to follow vertical line that is woven into your earthly life which you are called upon to be followed when the right time comes: thanatos. This thanatos concept is woven into Keynesian outlook and it is a matter of what might be considered as eschatological aspect of Keynesian economic theory expressed in the terms of "uncertainty", "long-term expectations", "imperfectness", "economic future", "theory of business cycles", "possibilities for our grandchildren".

\section{The Rise of Secular Economics}

Another question which is of my concern here, apart from economic terminology coined by Keynes - in order to understand the anomalies afflicted economic practice - is related with the birth and rise of "modern economic theory". This problem, tracing Charles Taylor, I see as the problem of interpretation of "mobilization" of the moral horizons - due to economical and technological progress maintained on the West. The phenomenon of mobilization of moral horizons appeared as certain response on the intellectual revolution occurred in the age of the Enlightenment and reinforced by $19^{\text {th }}$ century scientific and technological progress especially in the field of industry and manufacturing (mainly in the Anglo Saxon speaking world) (Aydon, 2009). $19^{\text {th }}$ century science was led by famous English evolutionary theorists (Darwin, Huxley, Spencer) whose scientific conception revolutionized entire Western academic and scientific world. Regarding the science of economy, what happened in the late $18^{\text {th }} \mathrm{c}$. and at the beginning of $19^{\text {th }} \mathrm{c}$. is intellectual revolution among scientific elites engaged with making economic theories

\footnotetext{
${ }^{1}$ The term „economic“ related to „community“ refers to family concept.
} 
based on (what I shall define as) nature processes law: so-called economics of the natural events ${ }^{1}$ is mapped to the policy of production and of social growth e. g. Malthus's Essay on Population - in our case - is quite good example of it.

Names related with "the pioneers of modern economics" (e. g. Smith, Mill, Malthus, Ricardo, Marx) usually found in highly-professional economic manuals are usually being designated as the proponents of "classic economic theory" - in shorter form: "the classics". So, we are speaking of capitalism as of new economic and social order established in the era when dominated outlook was empirical one. But, if we approach to the capitalism issue through historical prism, we can easily notice that - considering the forms of strategies applied to the capitalistic economy, we might say that we deal with very old pattern of governing the societies which was ruled by individuals who shared great interests in having control over the state budget, local (tribes) economies, their capital and ownership. All these things we have numbered here are specifically recognizable in the ancient Maya civilization during the Lady Six Sky regency in $7^{\text {th }}$ and $8^{\text {th }}$ c. A. D. (Phillips, 2008; Phillips and Jones, 2010).

\section{Ethics vs. Evolution and Economics?}

In further discussion I shall try to explain theoretical basis of secular ethics by tracing Thomas Henry Huxley in his Ethics and Evolution (Ruse [ed.], 2009). I shall start this discussion with the concept of natural processes economy.

The 'natural processes economy' is phrase I have coined on account of selected insights I have borrowed from David Attenborough's The Living Planet. $^{2}$ There is a certain synchronicity ${ }^{3}$ between different nature processes which operates in the nature according to the principle of similarity: between every element of the geographical structure of the Earth (e. g. forests, deserts, steppes, mountains etc.) as well as between every element that shapes body of different earthly creatures in the nature there is certain similarity - concerning the functions and operations of their organisms. This is Darwinian path. In addition to Darwin, another interested name related to the evolutionism is Th. H. Huxley. Although Huxley was proponent of evolutionism, his concept of evolution is beyond Darwinian one, because it is grounded in certain - indeed secular, but moral outlook. What Huxley did for ethical science is that he implemented the ethics concept into Darwin's evolutionary theory (or it was vice versa, ho knows!) (Ruse [ed.], 2009: xv) by emphasized the role of humans as morally engaged creatures in the evolutionary process due to significance of their agency. So, For Huxley itself, ethics is not a matter of conventions but of evolution. Thus, ethics might be understood as natural process that is evolutionarily designed and which humans have been adopting by time, and unlikely ancient Aristotelian conception, it does not depend on the given moral predisposition embedded in us and thus motivated by our natural

\footnotetext{
${ }^{1}$ My term for Darwinian evolutionary theory attached to the social sciences.

${ }^{2}$ The book I have found applicable to the roots of economics issue. What is remarkable in it is author's methodology of the given issues he is dealing with: the Earth life-processes mystery.

${ }^{3}$ Jung's term.
} 
desire of knowledge, but simply depends on the process of evolution. Therefore, Huxley takes feeling as the basis of morality, not the ratio - as ancient Greek thinkers did. Another peculiar name related to the 'science of economy"1 was "English evolutionist, sociologist, philosopher and very influential man in England of the $19^{\text {th }}$ century": Herbert Spencer. Spencer was engaged with the issues of evolution and economy. Unlikely Darwin, Spencer was - regarding his scientific outlook - more close to Huxley and has shown great interests in the role of humans in the evolutionary process (Ruse [ed.], 2009: xvi). Evolutionary process is designated by strong moral significance owing to man's place in it. The strongest defender of ethical evolutionism was neo-Spencerian Edward O. Wilson. Wilson was convinced that ethics can be justified by evolution: "(...) if ethics is not justified by evolution, then how is it justified? (Ruse [ed.], 2009: xxxiii). - There is no universal answer on this question that would be "generally accepted". Considering the ethics issue, we might be agreed with Huxley that ethics is capacity of "beating the beast within ourselves". Is it related with evolution or is it not, is a question that opens more new questions concerning the question of the human nature. But, our task is to investigate the role of ethics in the economics. In order to do that, we were obliged to re-think many topics related with it:

1. the Aristotelian approach to the economy issue related to the role of knowledge - of ratio;

2. the Keynesian impulse taken as an (economic) outlook which coincides with Aristotelian and Judeo-Christian one, especially in the segment referring to the future concept, so we might speak of temporal dimension of both Aristotle's and Keynes's concept of economy;

3. the question of mobilization referred to the evolutionary theory and the role of ethics in it;

4. the question of the meaning of the economics itself by revising historical facts concerning the major economic crisis in 1929 and 2008.

All things that are mentioned under 1 to 4 are deeply connected, so what we want (to do) here is to 'serve' some broader picture of that of how we got here where we still are: standing on the bottom of crisis which is certainly not economic, but moral one.

\section{Economy between Past and Future}

The concept of future (of human existence) is main Keynes's preoccupation in his prophetic essay issued at the very beginning of 1930s under the title Economic Possibilities for Our Grandchildren. In this essay that

\footnotetext{
${ }^{1}$ Author's term for economics which is multiply quoted in text above.
} 
is written nearly a century ago Keynes wrote that in one hundred years all kinds of economic problems will be vanished:

"(...) suppose that a hundred years hence we are all of us, on the average, eight times better off in the economic sense than we are today. Assuredly there need be nothing here to surprise us." (Keynes, 1930).

\section{The Year 1929}

One among many causes of the economic crisis of such a large scale as Big Depression is, was the imbalance in offer and supply that has occurred due to excessive production of goods which was disproportioned with weak consumption. For the economy itself, as Weitzman tracing Keynes explains in his Shared Economy, the problem of global crisis in 1929 was related with several economic problems:

1. rapid accumulation of commodity stocks in the market;

2. the amount of the goods went up;

3. the prices, together with the population of consumers, went down;

4. the companies and merchants could not sell their products, because people were suffering from the lack of cash-money;

5. the production was stopped due to lack of industrial resources;

6. the recession came out and

7. unemployment has risen. (Weitzman, 1993).

This is a brief story of how the 1929 has happened. But, what has caused the economic crisis phenomenon in 2008 is completely another story.

\section{New Crisis}

The term economy may refer to entire global and local system of production, distribution, welfare, many-making, etc. The key-factors of economy are man, land and capital. Economy is based on labor. Labor is spiritus movens of all economic activities that involve production, distribution, purchasing and consumption of goods. The unequal distribution of the goods in the world results with the problem that is a core of all economic problems - as economic practice has shown - still unsolvable one: poverty. Economic poverty is the greatest malice of modern capitalism ${ }^{1}$. It is caused by fallacious economic policy tailored by the Titans of global economy - those who are in charge in managing the strongest world economies (e. g. USA, Japan, China, Germany, United Kingdom and a like) for which some theorists have special name by calling them "G $6, \mathrm{G} 8$ or G 20 " 2 . Tracing M. Foucault, we might call

\footnotetext{
${ }^{1}$ I used term "modern" related to capitalism in order to differ it from the ancient form of protocapitalism applied by the Mayan ruler Lady Six Sky I have discussed here under title „The Rise of Secular Economics“.

${ }^{2}$ These acronyms are synonyms for the richest country in the world. As we can see: in 2007 we were discussing about the six of the most powerful economies in the world. But, what we can
} 
them the engine that turns the global "mechanism" of the economic "control and surveillance" over the global market.

Economic crisis in 2008 has appeared as the consequence of agency I have been explaining under the section "The year 1929". But, its touch stone was USA financial industry clash caused by unreliable economic policy carried out by USA Government, in that time led by notable names that have marked USA financial policy and industry and economic education, as well: A. Greenspan ${ }^{1}$, H. Paulson ${ }^{2}$, and others engaged with USA financial market's clash: Wall Street private bankers, the CEOs of the most notable New York investment banks ( Goldman \& Sachs, Merrill Lynch, J. P. Morgan, Morgan \& Stanley, the Lehman Brothers, Deutsche Bank); broker agencies, insurance houses $\left(A I G^{3}\right)$, and some names related to the world-known distinguished American higher educational institutions engaged with economics: Harvard University ${ }^{4}$, Columbia Business School.

\section{$\underline{\text { Survival of Small Economies }}$}

The economic consequences of the 2008 crisis - at global level - were enormous, especially for the small economies such as Island or Croatia. Croatia is state in transition, which went through certain political metamorphoses after the Berlin Wall clashed down at the end of 1980s. The economic consequences of the global crisis in 2008 for Croatian majority were pretty strong. I dare to say that it was certain moral and economic genocide perpetrated against Croatian population (which counts a bit more than 4,2 million of people). But, going backwards, Croatian economic crisis is more related with internal political problems rather than with global economic one: economic consequences of the privatization process initiated in early 1990s (time when has Croatian War of Independence started) is still at work. Consequentially, Croatian economy is characterized by very high rate of unemployment (nearly $400000^{6}$, but this figure varies from month to month within the current solar

notice is sudden jump from number 6 or 8 - in the year 2000 or 2007 to the number of 20 in the present time: „the rapidly growing market“ phenomenon has been already discussed by Keynes almost hundred years ago.

${ }^{1}$ Alan Greenspan is former chairman of American Federal Reserve from 1987 to 2006.

${ }^{2}$ Henry (Hank) Paulson is American banker and former Secretary of the Treasury and ex Goldman and Sachs CEO from 1998 to 2006, when he was appointed by ex American president George W. Busch for the Finance Minister Service.

${ }^{3}$ Acronym for American International Insurance Group, Inc. AIG is multinational insurance group founded by the very beginning of 20th century. One of its leading men was involved with the Lehman Brothers affair in 2008.

${ }^{4}$ Larry Summers, Harvard economist and professor, very complex figure in American financial policy and academic milieu. He was working as financial advisor in former Clinton Administration. He also served as chief economic adviser in president Obama's Administration. Summers is taken as the creator of the fallacious deregulatory policy which ruined the Lehman Brothers in the September 2008, thus caused the global financial crisis.

${ }^{5}$ The Dean of Columbia Business School, Mr. Glenn Hubbard who was serving in Busch's Administration as financial advisor is involved in recent economic crisis, too. According to his opinion, the USA financial industry is not responsible for the global crises.

${ }^{6}$ The current rate is 314723 of unemployed people according to data taken from the official Croatian Unemployment Office web-site accessed on 12th of Jun 2014. 
year). Description that follows can give us pretty plausible picture of the current status of Croatian economy:

1. constantly growing of unemployment;

2. increasing rate of consumption;

3. increasing interest for studying business, management and economics: current number of higher economics institution in Croatia goes over 170, what includes both public and private economic faculties and colleges;

4. reducing level of savings, but increasing level of loans and mortgages;

5. reducing level of production: recession and "stagflation".

What is more significant for Croatian society in crisis is shroud economic policy that has been implemented into Croatian economy since the beginning of 1990s. So-called privatization process which has been designed and developed in the beginning of nineties - in the down of Croatian independence struggling for democracy, at every level of life, included the status of the state economy. Many decades before Croatian War of Independence (1991-1995) during the communistic era (1945-1990) Croatian economy as integrative part of ex Socialistic Federate Republic of Yugoslavia - in that time led by former lifelong president Josip Broz - Tito (1892-1980) - was subordinated to repressive communistic policy: both business and economy were dictated by the state government. Capitalism was characterized as forbidden illusion that opposes widely spread Marxism. In that time on the Croatian academic stage (in 1970's) appeared extraordinary woman of sharp intellect: former Croatian politician and economist - Savka Dabčević-Kučar.

\section{Croatian Contribution to Keynesianism}

Savka was one among very rare Croatian scientists who reached doctoral title in economics in late fifties of $20^{\text {th }}$ century. Such intellectual step happened due to her doctoral thesis defended at the Faculty of Economics of University of Zagreb. Her contribution to Croatian economic science is immense because Savka was the one who introduced Keynes and his economic theory into Croatian economic science and academic milieu. In 1955 she defended doctoral thesis under the title John Maynard Keynes: Theorist of the State Capitalism. As the woman of very sharp intellect her scientific work opposed to onwards despotic regime conducted by communistic party, so, she was simply exiled from Croatian scientific, educational and political stage because of her pro-Croatian political and economical ideas. In such strict political milieu as Yugoslav communism was, it was unimaginable to write dissertation about capitalistic economist when widely accepted economic policy and theory was that of Marx. Thanks to Dabčević-Kučar Keynes has, metaphorically speaking, entered in the Croatian Economics through the window that was opened by female hand.

\footnotetext{
${ }^{1}$ Samuelson's term.
} 


\section{On Present Status of Business Ethics in Higher Economic Education}

\section{The Question of Acceptance of Ethics in Business Practice}

Concerning academic and educational milieu in general, I dare to claim that Business Ethics is not yet accepted, either in (economic) theory or in (business) practice. As the concept of morality is its primal subject of investigation, tracing Tugendhat, we might ask: What would be its epistemological base? The answer on this question is the same as of the question related to the moral base issue: there is no widely accepted answer. Furthermore, what ethics students of applied sciences should be taught; is ethics, as subject of studying, necessary within higher economic education syllabuses? - If the answer on given questions might be affirmative, we might ask: Why? - The only reasonable answer would be the one attached to economic practice itself: it is crisis itself Smithsonian "hand" that we can see, indeed. Economics needs Ethics in order to survive. Economics needs a shift towards humanistic perspective, weather we speak of (economic) theory applied to practice or of practice itself, and both are the subjects of studying within faculties of economics and applied colleges. Otherwise Keynesian prophecy related to the "uncertain future" of economy will be fulfilled. It would be very shameful because economics itself is noble science and requires noble approach and perfect knowledge, too in solving the problems. In Keynesian manner, it takes knowledge that goes beyond economics: an inclusive knowledge that goes beyond the one that modern science of economy offering us: the knowledge of prudence. Only the "prudent path" should be followed on the way to Keynesian prudent economic future. And what ethics is, but prudence itself?!

\section{Interpretation of Economic Problems: the Vicious Circle of Wealth}

Considering the status of Ethics in Croatian business practice - as we were discussing Croatian crisis syndrome in other to show in which direction goes economic education in the countries of South-East Europe (and, it seems it goes into direction of making pure profit instead of knowledge), some data give us testimony of number of 400 out of nearly $300000^{1}$ companies that had applied for "Code of Business Ethics" proclaimed by Croatian Chamber of Commerce $^{2}$ in 2005 . The problem, as I see it here, is of teleological nature: the question of final telos of economic education in general. My thesis is that bad business practice, especially in the field of finance (e. g. banking, brokerage, hedge-founding, mortgage trading etc.) is a result of economic theory that is not just erroneous itself, rather misinterpreted or abusive one. As John Maynard had almost a hundred years ago observed and widely discussed in his notable work: theoretical base of economic practice will remain problem as

\footnotetext{
${ }^{1}$ Source: http://www.jutarnji.hr/zavod-za-statistiku-otkriva--svaka-druga-tvrtka-u-hrvatskoj-ne ma-niti-jednog-zaposlenika-/1048882/ (accessed on 26th Jun 2014).

${ }^{2}$ The Ethical Code entitled as "The Code of Ethics in Business" can be reached at: http://www.atlantic.hr/media/uploads/kodeksi/code_of_etics_in_business.pdf (accessed at 26th Jun 2014).
} 
long as we are all in the run after progressive wealth (Keynes, 1930), but it is pointless because (as I have said already in previous lines): "in the long run" we will all be facing with thanatos.

\section{On Business Ethics Teaching Competence}

Another problem that is connected with the status of Business Ethics (weather we speak of it at global level or at local one) is the question of Business Ethics teaching competence. As we deal with discipline whose domicile is business world, ethics is originally philosophical discipline, in the broader sense defined as science of morality. But the problems arise when some economists and others are assured that everybody, no matter of their profession or occupation, are able to teach ethics. Te result is dreadful: complete lack of ethical knowledge, for an instance: the lack of terminology: the lack of knowledge related to basic ethical terms, theories and axioms; the lack of the structure of explanation and of evaluation of the given issue; the lack of tool necessary in solving ethical dilemmas. The practice speaks for itself. But ethical practice I have being involved has raised new teaching methods. One among many of them I tried to show here: it not originally mines, but tracing D. Elliot I might call it "ethics in the first person" (Elliot, 2007: 3). Teaching ethics in the first person asks for knowledge of great magnitude: interdisciplinary and transdisciplinary approach to the ethical issues attached to higher economic education and to business world, too.

\section{Epilog: Philosophical Roots of Economics}

This complete elaboration is certain example of how Business Ethics solves problems related to economic theory and practice. I wanted to show how ethical knowledge can be implemented in the situation specific to business practice and sciences of economy. My investigation of - I dare to say - shroud economic education began by reading highly professional economic literature (e.g. Samuelson and Nordhaus, Weitzman, A. Sen, E. Schumacher, Blanchard and Peale, P. Drucker, and - J. M. Keynes - of course, in order to understand the origins of economic instrumentalism widely spread in the conscious of contemporary young people - the students of Economics. By reading universal economic literature assigned by economics syllabuses world-widely, what I have discovered is purely pragmatic approach to the economic issues, theories, postulates and axioms. Pragmatic in my terms means approach focused on the outcomes of learning Economics in a sense of what is the value of profit itself and how it can be applicable into practice. Not a word of what Charles Taylor calls "l'human condition" (Taylor, 1989). In other words, I have discovered that great number of economic literature suffer from lack of humanistic - or better say - of philosophical thinking. Having some clue of Keynesian view of insufficiency of current economic theory which is formulated by the great pioneers of modern economy (or, so-called "the classics") made on the base of deep insight into Keynesian thought, I think that Keynes - as he was quite good connoisseur of Art and Philosophy (Minsky, 2008: 144-147), had Philosophy on his mind when he was talking about morality as of missing link 
in modern economics. Hence, I take Keynes as promoter of ethics in both economics and business practice, at least in the segment where he speaks of basic ethical notion missing in the real world: individual rights (e. g. right to private ownership - converges with Aristotelian outlook); social justice and equality (converges with Aristotle's, too) by constantly raising the rate of employment and reducing the rate of production and consumption. It is paradoxical, but possible, if we want to avoid any kind of future crisis. Hence, moral crisis is deeply connected with economic one. The last one is just "seen" consequence, not "unseen" - as Adam Smith taught 150 years ago. Attaching the question of the nature of the market itself that Smith discussed in his papers, my counter-claim is that "market mechanism" is directed by "hand" we see, but following Aristotle, Heidegger and Keynes, yet not recognized.

\section{Acknowledgement}

To all my colleagues from Balthazar Zaprešić University of Applied Sciences who have encouraged me over the years by their peculiar economic insights to investigate such waste area as Economics certainly is. I acknowledge to ATINER organizer, too, for being inviting me at $16^{\text {th }}$ Conference on Education, for which special purpose this paper is written.

\section{References}

Aristotle. 1982. Nicomachean Ethics. FPN - Liber. Zagreb.

Aristotle. 1988. Politics. Globus/Liber. Zagreb

Aydon, C. 2012. A Brief History of Mankind. Znanje. Zagreb.

Attenborough, D. 1990. The Living Planet. Prosvjeta. Zagreb.

Croatian employment Office. Official web-site - http://www.hzz.hr/ default.aspx.

Croatian Chamber of Economy. Official web-site - http://en.hgk.hr/.

Dabčević-Kučar, S. 1957. John Maynard Keynes: Theorist of the State Capitalism. Kultura. Zagreb.

Elliot, D. 2007. Ethics in the First Person. Rowman \& Littlefield Publishers Inc. Lanham-Boulder-New York-Toronto-Oxford.

Huxley, T. H. 2009. Ethics and Evolution, M. Ruse, Ed. Princeton University Press.

Keynes, J. M. 1930. Economic Possibilities for Our Grandchildren. In Essays in Persuasion, J. M. Keynes (1963), W. W. Norton \& Co. New York, pp. 358-373 http://www.econ.yale.edu/smith/econ116a/keynes1.pdf.

Keynes, J. M. 1936. General Theory of Employment, Interest and, Money

Minsky, H. P. 2008. John Maynard Keynes. McGraw Hill. New York at al.

Russell, B. 2005. Wisdom of the West. Marjan Publishing. Split.

Samuelson, P. A. \& Nordhaus, W. D. 2007. Economics [XVIII. Ed.]. MATE. Zagreb

Taylor, Ch. 1989. Sources of the Self: the Making of the Modern Identity. Harvard University Press. Cambridge, Massachusetts.

Taylor, R. \& CRAIG W. L. 1993. Is the Basis of Morality Natural or Supernatural?, New York/USA: Union College - http://www.reasonablefaith.org/is-the-basis-ofmorality-natural-or-supernatural-the-craig-taylor-debate. 
The Last Days of Lehman Brothers, documentary film - http://www.youtube.com/ watch?v=RLWIPyQXcRE.

Tugendhat, E. 2003. Lectures on Ethics. Jesenski \& Turk. Zagreb.

Weitzman, M. L. 1993. Shared Economy: Conquering Stagflation. AGM. Zagreb. 
